Оригиналан научни рад/ Original scientific paper

УДК/UDC: 005.311.11:338.48-44(1-22)(497.11)

doi: 10.5937/bizinfo2001001P

\title{
Measuring perception of service quality of Serbian rural tourism using RURALQUAL scale
}

\section{Merenje percepcije kvaliteta usluga u ruralnom turizmu Srbije primenom RURALQUAL skale}

\author{
Goran Perić $^{\mathrm{a} *}$, Sandra Dramićanin ${ }^{\mathrm{b}}$, Ace Milenkovski $^{\mathrm{c}}$ \\ ${ }^{a}$ Academy of Professional Studies South Serbia, Department of Business Studies Blace, Serbia \\ ${ }^{\mathrm{b}}$ University of Kragujevac, Faculty of Hotel Management and Tourism in Vrnjačka Banja, \\ Serbia \\ ${ }^{\mathrm{c}}$ University of Tourism and Management, Skopje, North Macedonia
}

\begin{abstract}
The aim of this research is to measure the perception of services quality in rural tourism in the Republic of Serbia using the RURALQUAL scale, and to determine its factor structure as well. The research was conducted during January and February 2020, using the questionnaire technique, on a sample of 298 respondents. The findings of the descriptive statistical analysis indicate a high assessment of the perception of service quality in rural tourism in the Republic of Serbia, while professionalism and basic advantages were singled out as the most important dimensions of service quality. The assessment of the perception of the actually provided service is the lowest for the tangibility dimension. The principal components analysis singled out three factors that explain $57.87 \%$ of the variance. The principal components analysis findings, after rotation produced a clear factor structure with relatively high loading and minimal item overlap, indicating factor independence. Factors are marked as: professionalism and basic benefits; tangibility and reservation; complementary benefits and environment. Therefore, measuring the perception of service quality through the RURALQUAL scale can help owners of rural tourist lodgings in obtaining feedback on the quality service provided, in order to implement an adequate strategy to improve the quality of services in rural tourism. Research limitations are presented and recommendations for future research are given.
\end{abstract}

Keywords: service quality, perception, rural tourism, RURALQUAL.

Sažetak: Cilj ovog istraživanja je merenje percepcije kvaliteta usluga u ruralnom turizmu Republike Srbije primenom RURALQUAL skale, kao i utvrđivanje njene faktorske strukture.

${ }^{*}$ Corresponding author.

E-mail address: goran.peric@vpskp.edu.rs 
Istraživanje je sprovedeno tokom januara i februara meseca 2020. godine, tehnikom upitnika, na uzorku od 298 ispitanika. Nalazi deskriptivne statističke analize ukazuju na visoku ocenu percepcije kvaliteta usluge u ruralnom turizmu Republike Srbije, dok se kao najvažnije dimenzije kvaliteta usluga izdvojile profesionalizam i osnovne prednosti. Ocena percepcije stvarno pružeme usluge najniža je za dimenziju opipljivost. Ekplorativna faktorska analiza izdvojila je tri faktora koji objašnjavaju $57.87 \%$ varijanse. Nalazi faktorske analize su nakon rotacije proizveli jasnu strukturu faktora sa relativno visokim loading-om i minimalnim preklapanjem stavki, što ukazuje na nezavisnost faktora. Faktori su označeni kao: profesionalizam i osnovne prednosti; opipljivost i rezervacija; komplementarne prednosti $i$ okruženje. Dakle, merenje percepcije kvaliteta usluga putem RURALQUAL skale može pomoći vlasnicima ruralnih turističkih domaćinstava u dobijanju povratnih informacija o kvalitetu pružene usluge, a u cilju primene adekvatne strategije za unapređenje kvaliteta usluga $u$ ruralnom turizmu. Predstavljena su ograničenja istraživanja i date preporuke za buduća istraživanja.

Ključne reči: kvalitet usluga, percepcija, ruralni turizam, RURALQUAL

\section{Introduction}

Rural tourism has been growing rapidly in recent decades. Such a trend has been influenced by numerous factors: people choose to go on shorter trips, return to nature and original values, travel more often with their own car, explore new landscapes and crave new experiences. The need to stay in rural areas, such as rural lodgings, is imposed by a modern lifestyle, and rural tourism offers modern tourists a return to nature and people. With daily stress, fast-paced lifestyle, lack of time and high-quality activities, rural tourism is an opportunity to escape from everyday life with the possibility of spending a pleasant vacation. It is important for the product of rural tourism to provide personal contact and the opportunity to participate in activities, traditions or lifestyles in rural lodgings to tourists. The development of this popular form of tourism affects the revitalization of rural areas, improving the social structure of rural areas and the economic condition of rural lodgings, which are the basis of the overall development of rural areas and contribute to preserving and promoting spiritual and material values and environmental protection.

The Republic of Serbia has great potential for the development of rural tourism, given its natural beauty combined with culture, tradition, festivals, gastronomic specialties and music (Đenadić et al., 2016). As a country of rural character, it is one of the agrarian countries in Europe. Rural development is a key instrument for restructuring the agricultural sector and has the task of focusing and strategically exploiting the potential of tourist-attractive rural areas. The opposite way from fast-paced modern life, rural life includes activities such as long walks and recreation, enjoying the sounds of nature and the tastes of food made from proven ingredients. These are exactly motives for coming to rural areas: peace, clean environment, interaction with new people, healthy food, slower pace of life and free time. All these motives are responsible for the development and survival of rural tourism as a tourism oriented to the individual tourist and his needs.

Given the pronounced economic and other functions of tourism, as well as diverse and very valuable potentials, opportunities and examples of importance, rural tourism is treated as a priority and is related to tourism of special interests. In order to use the 
full potential of rural tourism in the Republic of Serbia and create a sustainable, competitive product of rural tourism, it is necessary to conduct market research and the needs, motives and preferences of tourists. Rural tourism significantly enriches the tourist offer and provides a new quality and encouragement for the development of this type of tourism in Serbia (Muhi, 2010).

The perceived quality of rural tourism offer is crucial for the competitive advantage of a rural destination. The service quality that the tourist expects and learns should be the first thing that service providers, destination managers and other stakeholders take when constructing a tourism product related to rural tourism. The quality of service in rural tourism can be viewed from different points of view and most often depends on the perspective of tourists, because it is often a very subjective evaluation of the services received. The service quality has its own specifics in rural tourism. Quality construction encompasses more than measurable and empirical attributes (Chen \& Chen, 2010). The basis for assessing the quality of rural tourism services are the tangible and intangible attributes of these services. The quality of the service depends on the expectations of the tourist before he experiences the service with the performance of the service delivery system, starting from advertising, through previous experiences to culture (Parasuraman, et al., 1985). The complexity and globalization of the modern competitive business environment in rural tourism has made quality one of the biggest sources of competitive advantage, and therefore attracted attention for research, because research of the quality rural tourism is rare (Loureiro \& González, 2008). In the domestic literature, empirical research of service quality in rural tourism does not exist. The aim of this research is to measure the perception of the service quality in rural tourism in the Republic of Serbia using the RURALQUAL scale, as well as to determine its factor structure. Accordingly, research questions are defined: What is the perception of service quality in rural tourism in the Republic of Serbia? What factor structure does the RURALQUAL scale have? Is the scale structure in this study, used on a sample of respondents in the Republic of Serbia, consistent with previous research?

\section{Literature review}

\section{Rural tourism}

The changes that are occurring at the global level affect the development of selective forms of tourism, primarily the development of tourism in rural areas. Rural tourism is able to solve numerous problems, especially the imbalance that has been expressed in recent years in the rural-urban relationship, depopulation of rural areas and enable the urban population to find their roots, lost cultural values, peace and tranquility (Gašić, 2016). Nowadays, intensive urbanization accompanied by a stressful lifestyle in urban areas, then lack of quality activities and time, have created an increased demand for living in rural areas (Lane, 1994), which provides a sense of calm, freedom and relaxation, which is in contrast with modern way of life in urban areas (Gašić et al., 2015).

Rural areas have been underdeveloped and uninteresting until recently come to the fore, because they represent a great potential for the development of rural tourism 
(Milićević et al., 2015), and increased tourism activity plays an important role in their development, because it involves economic and non-economic activities in rural areas (Jurdana \& Frleta, 2012; Podovac et al., 2019). Accordingly, the development of rural tourism improves the economic position and social activity of the rural population (Mandarić et al., 2017). Rural tourism is a growing market segment in all developed countries (Chuang, 2010; Koster \& Lemelin, 2009; Lee \& Kim, 2009; Loureiro \& González, 2008), there are numerous challenges in finding new products and services that will meet the growing demand to stay in rural areas.

There is no generally accepted definition of rural tourism in the literature (Frochot, 2005). Rural tourism, according to the definition accepted in 1986. within the European Union, includes all tourist activities in rural areas (Demonja \& Ružić, 2010). One of the most common definitions defines rural tourism as "tourism that takes place in rural areas" (Lane, 1994). According to Loureiro et al. (2019), rural tourism is defined as "a tourist niche that includes several rural products (local food, rural accommodation, fairs and participation in rural activities and focuses on preserving local architecture, historical heritage and natural environment)". A similar definition was given by Rabotić (2013) according to which rural tourism describes the forms of tourist activities that take place in rural areas and that include local culture, tradition and economic activities, as well as outdoor activities and experiences realized in undisturbed rural environment.

The strong basis for the development of rural tourism in the Republic of Serbia is the large number of traditional rural lodgings, preservation, attractiveness and richness of natural resources, as well as a large number of cultural and historical monuments (Novaković \& Perić, 2018; Pavlović, 2016; Gašić et al., 2015). Despite that, rural tourism is not going according to its possibilities. The development of rural tourism in the Republic of Serbia, as an organized activity, began a little over a quarter of a century ago (Gašić et al., 2015) and is still in the initial phase of development. Fragmented and dispersive rural holdings, turn towards other types of tourism and mass, insufficiently developed awareness of the value of the environment, are just some of the factors that have influenced the poor development of rural tourism. Also, the weak appearance of rural tourism in the tourist offer of the Republic of Serbia has led to the current results (Todorović \& Bjeljac, 2007).

The accommodation data in rural tourism are not covered by official statistics yet. The types of accommodation facilities in rural tourism are shown in the following table.

Table 1. Types of accommodation facilities in rural tourism of the Republic of Serbia

\begin{tabular}{lcc}
\hline \multicolumn{1}{c}{ Accommodation types } & Accommodation number & \% \\
\hline Apartments & 50 & 20.57 \\
Log cabins and wooden house & 26 & 10.69 \\
Ethno villages & 1 & 0.42 \\
Guest houses & 42 & 17.28 \\
Hostels & 1 & 0.42 \\
\hline
\end{tabular}


Table 1. (Continued)

\begin{tabular}{lcc}
\hline \multicolumn{1}{c}{ Accommodation types } & Accommodation number & \% \\
\hline Motels & 1 & 0.42 \\
Boarding house & 5 & 2.06 \\
Lodging & 5 & 2,06 \\
Rural households (lodgings) & 82 & 33.74 \\
Rooms & 7 & 2.88 \\
Private apartments & 1 & 0.42 \\
Tourist resorts & 2 & 0.82 \\
Tourist facilities & 2 & 0.82 \\
Cottages & 9 & 3.7 \\
Villa & 9 & 3.7 \\
In total & $\mathbf{2 4 3}$ & $\mathbf{1 0 0}$ \\
\hline
\end{tabular}

Source: Gašić, M., Perić, G., \& Ivanović, V. (2015). Development of rural tourism in the Republic of Serbia. BizInfo (Blace), 6 (2), 71-81.

The number of lodgings engaged in rural tourism is probably far higher than the data shown in the previous table, but they are engaged in this activity independently, unorganized and offline, so there is no precise information about them. In the total number of current service providers in rural tourism in the Republic of Serbia, the most numerous are rural lodgings, apartments and guest houses, of which there are 174 , which represents $71.59 \%$ of the total number of rural accommodation capacities. According to local tourism organizations, rural tourism is supported by more than 32,000 registered and unregistered beds in rural areas, of which 10,000 are exclusively in the countryside (Đorđević, Milošević \& Milovanović, 2012). The municipalities of Gornji Milanovac, Čajetina, Valjevo, Arilje, Kosjerić and Ljig have the largest number of rural accommodation capacities (Gašić et al., 2015).

Organized statistical monitorings of this segment of tourism are at the beginning. A large number of countries, including the Republic of Serbia, do not collect statistical data, in which rural tourism would be observed separately in relation to other forms of tourism, and according to the Republic Bureau of Statistics, tourist traffic in other places can be considered tourist traffic within rural tourism (Radović, 2013). According to some estimates, rural tourism in the Republic of Serbia participates with about 25\% in the total tourist traffic (Gašić et al., 2015; Radović, 2013; UNWTO, 2011).

\section{Service quality}

A systematic approach to quality management in production, began to develop in the 1920 s, in contrast to the quality of services that was neglected until the 1980s. The development of the tertiary sector and tertiary activities, the quality of services gained in importance, because almost two thirds of world income is generated in the tertiary sector, which is slightly more productive than industry (Tornjanski, 2016). The definitions of services encounter in the literature are different, depending on the authors and their observation of services in the economy (Veljković, 2018). For example, Palmer (2011) defines "a service as any benefit or activity offered by one side to the other, which is essentially intangible and which does not own any element of the service". One of the most commonly used definitions was presented by 
Lovelock according to which "service is an act or performance offered by one side to another" (Bowen \& Ford, 2002). Although the process may be tied to a physical product, the performance itself is intangible and does not result in ownership of any factor of production (Bowen \& Ford, 2002). These definitions indicate that the service is of an intangible nature, respectively it is intangible, which means that its quality is not easy to define and determine. Grönroos (1984) was the first who mark off two dimensions of service quality - technical and functional quality, where technical quality refers to what the consumer actually gets from the service, while functional quality refers to how the consumer receives that service. Grönroos has opinion that the technical side of service quality should not be neglected, but points out that functional quality is the most important factor in assessing service quality (Grönroos, 1984). According to Parasuraman et al. (1985), service quality is the difference between consumer expectations and the perception of delivered service. Cadotte and Turgeon (1988) have a similar opinion, according to which the quality of services arises from a comparison of consumer expectations about what kind of service they will receive and perceptions of the service actually provided. Choi and co-workers (2018) believe that the quality of services is the main factor in differentiating services and achieving competitiveness in tourism.

The impact that the service quality has on consumer satisfaction has conditioned the development of several models for evaluating and improving the quality of services. Researchers point out that the concept of service quality is very complex and needs to be measured by a series of variables grouped into dimensions (Parasuraman et al., 1988; Parasuraman et al., 1985; Grönroos, 1984). Therefore, each dimension of service quality represents a series of service attributes that consumers question when evaluating the service dimension (Ahrholdt et al., 2017). Parasuraman et al. (1988, 1991, 1994) developed a quality measurement model known as SERVQUAL that allows to compare consumer perception with his expectations and therefore to notice the difference between expected and delivered service. The original model contained ten dimensions, which were later reduced to five: tangibility, reliability, responsibility, security and empathy (Parasuraman et al., 1988, 1991, 1994). It is the most commonly used model for measuring the quality of services. Criticizing the SERVQUAL model, Cronin and Taylor $(1992,1994)$ developed the SERVPERF model for measuring service quality based only on perception, while no importance is attached to expectations. They believe that the quality of services can be equated with the attitude of consumers. Also, they point out that consumers do not always consume services of the highest quality, but those that offer the highest value in certain circumstances.

With the development of rural tourism, the need to understand the service quality in rural tourism has grown. Accordingly, a RURALQUAL model for measuring the service quality in rural tourism has been developed based on the SERVQUAL model, assessing only consumer perception (Loureiro \& Kastenholz, 2011; Loureiro \& González, 2009), such as the SERVPERF model (Cronin and Taylor, 1992, 1994). The model consists of 22 questions divided into six dimensions: professionalism, reservation, tangibility, complementary advantages, rural and cultural environment and basic benefits (Loureiro, 2012; Loureiro \& Kastenholz, 2011), while in the original model there was no reservation dimension (Loureiro \& González, 2009). 


\section{Methodology}

\section{Measurement}

The questionnaire for this research is divided into three categories: a description of the research, questions that measure the perceived service quality in rural tourism and questions about the demographic characteristics of the respondents. The RURALQUAL scale (Loureiro \& Kastenholz, 2011; Loureiro \& González, 2009) was used to measure the perception of service quality in rural tourism in Serbia. The assessment of service quality is based on the perception of the actually provided service, ie the service experienced (Kang, 2006; Cronin \& Taylor, 1992, 1994). Respondents assessed the perceived service quality in rural tourism based on 22 questions, which were divided into six dimensions. Respondents assessed the degree of agreement with the given questions using a five-point Likert scale $(1=$ strongly disagree to $5=$ strongly agree). Finally, the respondents stated their gender, age, level of education and place of residence. Descriptive statistical analysis was applied to describe the sample, as well as to assess the perception of service quality in rural tourism in Serbia, with the initial dimensions of quality.

\section{Sample and Data Collection}

The collection of primary data was performed using the questionnaire technique, which includes the method of research which systematically collects data from a set of respondents in the form of personal views. The research was conducted during January and February 2020, through an online questionnaire, which was distributed through open and closed groups on the social network Facebook. Respondents were informed that participation in the research was anonymous and voluntary, and that the results would be used exclusively for scientific research purposes. The sample on which the analysis was performed consisted of 298 respondents. There is no missing data among these 298 respondents. The characteristics of the respondents are shown in Table 1.

Table 2. Demographic characteristics of respondents

\begin{tabular}{lcc}
\hline & \multicolumn{2}{c}{ Frequency $(N=298)$} \\
\cline { 2 - 3 } Gender & \multicolumn{2}{c}{$N$} \\
Male & 169 & 56.5 \\
Female & 129 & 43.5 \\
Age & & \\
Up to 19 & 7 & 2.3 \\
$19-24$ & 32 & 10.7 \\
$25-34$ & 94 & 31.5 \\
$35-44$ & 87 & 29.2 \\
$45-59$ & 69 & 23.2 \\
Over 60 & 9 & 3.0 \\
\hline & & (Continued)
\end{tabular}


Table 2. (Continued)

\begin{tabular}{lcc}
\hline & \multicolumn{2}{c}{ Frequency $(N=298)$} \\
\cline { 2 - 3 } & $N$ & $\%$ \\
\hline Level of education & 5 & 1.7 \\
Primary school & 72 & 24.2 \\
Secondary school & 130 & 43.6 \\
College/University & 91 & 30.5 \\
Master/PhD & & \\
Residence/Regions & 80 & 26.8 \\
Vojvodina & 108 & 36.2 \\
Belgrade & 22 & 7.4 \\
Sumadija and Westren Serbia & 80 & 26.8 \\
Southern and Eastern Serbia & 8 & 2.7 \\
Forgein Contries &
\end{tabular}

Source: Author's calculation based on SPSS 21.0

From total number of respondents, a larger share are women $(56.5 \%)$ compared to men (43.5\%). Over half of the respondents (60.7) are between 25 and 44 years old. According to level of education, respondents are mostly highly educated, the most respondents $(43.6 \%)$ belong to the category of higher education and university education, followed by respondents who have completed master's or PhD studies $(30.5 \%)$, and respondents with secondary $24.2 \%$ and primary school $1.7 \%$. The largest number of respondents is from the region of Belgrade $(36.5 \%)$, followed by the regions of Southern and Eastern Serbia (28\%) and Vojvodina (26.8\%), while the least number of respondents is from the region of Šumadija and Western Serbia (6\%) and from abroad ( $2.7 \%)$.

\section{Principal components analysis}

In order to determine the factor structure of the RURALQUAL scale and the dimensions of the perception of service quality in rural tourism, principal components analysis (PCA) with verimax rotation was applied. Data adequacy verification for PCA was performed. A sample size of 298 subjects was sufficient for PCA, observed in absolute terms (Pearson and Mundform, 2010). If the ratio of the number of respondents and the number of variables is observed, the sample size is also adequate, because the recommendations are that the ratio is around 10: 1, which in this case is also satisfied. The strength of the correlation between the variables was checked by means of a correlation coefficient matrix by calculating the Kaiser-Meyer-Olkin (KMO) adequacy measure and the Bartlett's sphericity test (Tabachnick et al., 2007). The KMO sample adequacy measure is 0.943 , which is significantly above the recommended value of 0.6 , and Bartlett's sphericity test shows that it is significant $(\chi 2$ $(231)=3586.56 ; \mathrm{p}=0.00)$, which indicates that the data are adequate for PCA, that there is a significant correlation between variables. There are many coefficients in the correlation coefficient matrix that are greater than 0.3 , which also indicates the adequacy of the data for PCA. The determinant is very close to 0 , which means that there is a high collinearity. 


\section{Results and discussion}

The results of the descriptive statistical analysis on the perception of service quality in rural tourism of Serbia with the initial dimensions of quality are shown in Table 3.

Table 3. The results of the descriptive statistical analysis

\begin{tabular}{|c|c|c|c|}
\hline Factor/Items & Mean & $\begin{array}{c}\text { Std. } \\
\text { Deviation } \\
\end{array}$ & $\begin{array}{l}\text { Cronbach's } \\
\text { Alpha }\end{array}$ \\
\hline Professionalism & 4.32 & 637 & 0.79 \\
\hline The rural lodging food is well presented and flavorful. & 4.50 & .735 & \\
\hline $\begin{array}{l}\text { The rural lodging employees have a clean and neat } \\
\text { appearance. }\end{array}$ & 4.12 & .870 & \\
\hline The clients are treated cordially and affably. & 4.44 & .746 & \\
\hline A personalized attention is provided to each client. & 4.21 & .885 & \\
\hline Reservation & 4.05 & .755 & 0.71 \\
\hline $\begin{array}{l}\text { The schedule of arrivals has been determined, but there } \\
\text { is a possibility of reservation moving. }\end{array}$ & 3.98 & .928 & \\
\hline It is easy to book accommodation. & 4.11 & .917 & \\
\hline $\begin{array}{l}\text { Reservations are confirmed in the best way for the } \\
\text { clients and all necessary informations are sent. }\end{array}$ & 4.07 & .990 & \\
\hline Tangibility & 3.96 & .814 & 0.87 \\
\hline The rural lodging facilities are in good condition. & 3.93 & .968 & \\
\hline Rural lodging and rooms have comfortable furniture. & 4.01 & .908 & \\
\hline The rural lodging is well acclimated. & 3.64 & 1.08 & \\
\hline The rural lodging facilities and rooms are clean. & 4.26 & .841 & \\
\hline Complementary benefits & 4.01 & .738 & 0.63 \\
\hline $\begin{array}{l}\text { Materials and objects from the local tradition are used } \\
\text { for decoration. }\end{array}$ & 4.23 & .833 & \\
\hline The rural lodging access is easy. & 3.58 & 1.08 & \\
\hline The lodging offers easy parking. & 4.23 & .933 & \\
\hline Rural and cultural environment & 3.99 & .746 & 0.79 \\
\hline The clients are integrated in region's way of rural life. & 3.87 & .940 & \\
\hline $\begin{array}{l}\text { The menu of the rural lodging contains dishes that are } \\
\text { characteristic for the region. }\end{array}$ & 4.40 & .782 & \\
\hline $\begin{array}{l}\text { The access to cultural, recreation, and sport activities is } \\
\text { facilitated. }\end{array}$ & 3.87 & 1.01 & \\
\hline $\begin{array}{l}\text { In the surrounding region exists fairs, special parties, } \\
\text { and other aspects of cultural interest. }\end{array}$ & 3.82 & 1.02 & \\
\hline
\end{tabular}


Table 3. (Continued)

\begin{tabular}{lccc}
\hline \multicolumn{1}{c}{ Factor/Items } & Mean & $\begin{array}{c}\text { Std. } \\
\text { Deviation }\end{array}$ & $\begin{array}{c}\text { Cronbach's } \\
\text { Alpha }\end{array}$ \\
\hline Basic Benefits & $\mathbf{4 . 3 3}$ & $\mathbf{. 6 4 4}$ & $\mathbf{0 . 7 7 1}$ \\
Employees in rural lodging know their responsibilities. & 4.25 & .939 & \\
The lodging architecture has the region's style. & 4.16 & .879 & \\
The place where lodging is located has a great natural & 4.53 & .738 & \\
beauty. & & & .773 \\
The lodging is located in a calm place. & 4.40 & & \\
\hline
\end{tabular}

Source: Author's calculation based on SPSS 21.0

The findings of the descriptive statistical analysis indicate a high assessment of the perception of the actually provided service in rural lodgings, which is in line with the results obtained by Loureiro and Kastenholz (2011). Relatively similar results were obtained by Kljaić Šebrek (2020) applying the modified RURALQUAL scale. Average ratings of guests' perceptions of the service quality in rural lodgings range from 3.58 to 4.53 , where the lowest score is access to a rural lodgings, while the highest score was given to the variable "place where the rural lodgings is located it has great natural beauty." As the least important dimension of the service quality, the respondents assessed the tangibility related to the conditions of accommodation in rural lodgings $(\mathrm{M}=3.96 ; \mathrm{SD}=.814)$. This finding is in contrast to the finding made by Kljaić Šebrek (2020) examining the perception of the quality of services in rural lodgings in the Istrian region in Croatia. Then follow the dimensions of rural and cultural environment $(\mathrm{M}=3.99 ; \mathrm{SD}=.746)$ and complementary advantages $(\mathrm{M}=$ 4.01; $\mathrm{SD}=.738)$. Respondents singled out the main advantages $(\mathrm{M}=4.33 ; \mathrm{SD}=.644)$ and professionalism $(\mathrm{M}=4.32 ; \mathrm{SD}=.637)$ as the most important dimensions of quality, followed by the dimension that speaks of reservation $(\mathrm{M}=4.05 ; \mathrm{SD}=.755)$. All dimensions of service quality have adequate reliability $(\alpha>0.7)$, except for the dimension of complementary advantage whose reliability coefficient is $\alpha=0.63$ (DeVellis, 2016).

PCA was performed on the RURALQUAL scale for measuring the perception of service quality in rural tourism has 22 questions, with the aim of determining the factor structure of the scale. The PCA results according to Kaiser's criterion suggest a 3factor solution that explains $57.87 \%$ of the variance. All factors whose eigen value is greater than 1 have been retained, and the reliability of all identified factors is very good $(\alpha>0.80)$. PCA findings after rotation produced a clear factor structure with relatively high loading and minimal overlap between items, indicating factor independence. In the final factor structure, the question "the schedule of arrivals has been determined, but there is a possibility of reservation moving" is excluded from the analysis because it has a very low degree of explanation of variance. Factors identified by PCA are labeled as: professionalism and basic benefits, tangibility and reservation and complementary benefits and environment. The following table summarizes the PCA results. 
Tabela 4. Results of principal components analysis with varimax rotation

\begin{tabular}{|c|c|c|c|c|}
\hline Factor/Items & Loadings & Eigenvalue & $\begin{array}{c}\% \text { variance } \\
\text { explained }\end{array}$ & $\begin{array}{c}\text { Cronbach's } \\
\text { Alpha }\end{array}$ \\
\hline Professionalism and basic benefits & & 9.78 & 20.95 & 0.88 \\
\hline
\end{tabular}

The rural lodging food is well presented and flavorful.

.663

The clients are treated cordially and affably.

A personalized attention is provided to each client.

Materials and objects from the local tradition are used for decoration.

The menu of the rural lodging contains dishes that are characteristic for the region.

Employees in rural lodging know their responsibilities.

The lodging architecture has the region's style.

The place where lodging is located has a great natural beauty.

The lodging is located in a calm place.

\section{Tangibility and reservation}

$1.79 \quad 20.55 \quad 0.89$

The rural lodging employees have a clean and neat appearance.

The reservations of rooms are easily accomplished.

Reservations are confirmed in the best way for the clients and all necessary informations are sent.

The rural lodging facilities are in good condition.

Rural lodging and rooms have comfortable furniture.

The rural lodging is well acclimated.

The rural lodging facilities and rooms are clean. 
Table 4. (Continued)

\begin{tabular}{lcccc}
\hline \multicolumn{1}{c}{ Factor/Items } & Loadings & Eigenvalue & $\begin{array}{c}\% \text { variance } \\
\text { explained }\end{array}$ & $\begin{array}{c}\text { Cronbach's } \\
\text { Alpha }\end{array}$ \\
\hline $\begin{array}{l}\text { Complementary benefits and } \\
\text { environment }\end{array}$ & & 1.15 & 16.36 & 0.81 \\
$\begin{array}{l}\text { The rural lodging access is easy. } \\
\text { The lodging offers easy parking. }\end{array}$ & .552 & & & \\
$\begin{array}{l}\text { The clients are integrated in region's way } \\
\text { of rural life. }\end{array}$ & .667 & & & \\
$\begin{array}{l}\text { The access to cultural, recreation, and } \\
\text { sport activities is facilitated. }\end{array}$ & .773 & & & \\
$\begin{array}{l}\text { In the surrounding region exists fairs, } \\
\text { special parties, and other aspects of }\end{array}$ & .777 & & \\
cultural interest.
\end{tabular}

Note: Total explained variance $=57.87 \%$, KMO measure of sampling adequacy $=.943$, Bartlett's test of sphericity $=3586.56, \mathrm{p}<.000$

Source: Author's calculation based on SPSS 21.0

The first factor professionalism and basic benefits contains nine questions. The questions refer to the attitude of the employees- host towards the guests, gastronomic offer, rural architecture and natural beauties. The factor explains $20.95 \%$ of the variance and has a reliability coefficient $\alpha=0.88$. Tangibility and reservation, as the second factor, contains seven questions and explains $20.55 \%$ of the variance, and its reliability coefficient is $\alpha=0.89$. Issues within this factor relate to tangible elements, such as accommodation facilities and their equipment, the appearance of employees and the manner of reserving accommodation. The third factor of complementary benefits and environment explains $16.36 \%$ of the variance and has a reliability coefficient $\alpha=0.81$. This factor contains five issues related to access to rural lodgings, inclusion in rural life and an environment that offers access to events, cultural and sporting activities.

The factors isolated by principal components analysis in this study do not match the theoretical model (Loureiro \& Kastenholz, 2011) which singled out six factors, while in this study three factors with relatively high loading and minimal overlap between items, which primarily indicates the independence of the factors. Practically, the six dimensions from the theoretical model are classified into three factors. A small number of studies have been engaged the perception of service quality in rural tourism. However, the conducted studies identified different results, both in terms of number and in terms of interpretations of the dimensions that guests use to assess the quality of the service actually provided in rural lodgings. Albacete-Saez et al. (2007) in their study of a sample of 172 respondents identified seven dimensions of service quality: personnel response; complementary offer; tourist relations; tangible elements; basic demands; security and empathy. The percentage of explained variance is $62.12 \%$ with a high reliability coefficient $\alpha=0.93$. Their research confirmed the thesis that the quality of services in rural lodgings is a multidimensional concept. Loureiro and González (2009) identified five dimensions in the original RURALQUAL model: 
professionalism; basic offer; rural and regional environment; complementary offer and tangibility. The reliability coefficient by dimensions ranged from 0.73 to 0.82 . In the later RURALQUAL model, the reservation dimension was added to the existing dimensions (Loureiro \& Kastenholz, 2011). Here, the reliability coefficient ranged from 0.75 to 0.84 . Kljaić Šebrek (2020) examining the perception of the quality of services in rural lodgings in the Istrian region in Croatia, factor analysis identified five factors: safety, relationship with tourists and the rural environment; tangible elements and basic requirements; reservations and price; professionalism and empathy. The percentage of explained variance is $65.17 \%$ with a coefficient of reliability by dimensions from 0.78 to 0.93 . The dimensions of professionalism and empathy fully coincide with the tested theoretical model (Loureiro \& Kastenholz, 2011). Accordingly, the number and interpretation of dimensions depends primarily on the context of measurement (Marković \& Raspor, 2010).

\section{Conclusion}

In this research, the perception of the service quality in rural tourism of the Republic of Serbia was measured by applying the RURALQUAL scale and the factor structure was determined on the basis of the applied scale. The service quality has become a significant element in the business of rural lodgings, and it is crucial to measure the service quality and accordingly the continuous improvement of services.

The results of the descriptive statistical analysis indicate a high assessment of the perception of the actually provided service in rural lodgings. Professionalism and basic benefits were singled out as the most important dimensions of service quality, while respondents were the least satisfied with the tangibility dimension, which implies the need for further improvement of accommodation conditions in rural lodgings. Also, another dimension of service quality that needs to be improved relates to the rural and cultural environment. In order to improve the service quality in this domain, it is necessary to involve guests more in everyday rural life (winter storage, preparation of traditional dishes, livestock keeping, field work and similar activities). Certainly, it is necessary to provide guests with access to cultural and recreational activities, as well as events. In order to increase the tourist offer in this domain, good organization, networking of lodgings engaged in rural tourism and support of local self-government are necessary. The principal components analysis identified three factors, namely: professionalism and basic benefits, tangibility and reservation, and complementary benefits and environment. The results of this analysis indicate that the six dimensions of the RURALQUAL scale are classified into three factors, the dimensions of service quality in rural tourism.

It can be concluded that the original RURALQUAL scale with six dimensions and a scale with a factor structure of three factors identified in this study, can help rural lodgings owners, as well as destination management in obtaining reliable data on guests' attitudes regarding perceived service quality, in order to implement adequate strategies for improving the quality of services in rural tourism. Accordingly, it is recommended to owners and destination management to periodically measure the service quality in rural tourism. 
It is necessary to point out the limitation of the research, which primarily refers to the structure of the respondents, which includes exclusively domestic tourists, having in mind the fact that only two percent of foreign tourists are in the total sample. Therefore, the interpretation of the results is limited to domestic tourists only. In the future research, domestic and foreign tourists should be examined equally, in order to get a complete picture and possibly determine the differences in the perception of the service quality in rural tourism. Also, future research should test the factor structure proposed in this study.

\section{REFERENCE}

Albacete-Saez, C. A., Fuentes-Fuentes, M. M., \& Lloréns-Montes, F. J. (2007). Service quality measurement in rural accommodation. Annals of Tourism Research, 34(1), 45-65. https://doi.org/10.1016/j.annals.2006.06.010

Ahrholdt, D. C., Gudergan, S. P., \& Ringle, C. M. (2017). Enhancing service loyalty: The roles of delight, satisfaction, and service quality. Journal of Travel Research, 56(4), 436-450. https://doi.org/10.1177/0047287516649058

Bowen, J., \& Ford, R. C. (2002). Managing service organizations: Does having a "thing" make a difference?. Journal of management, 28(3), 447-469. https://doi.org/10.1016/S0149-2063(02)00135-6

Cadotte, E. R., \& Turgeon, N. (1988). Key factors in guest satisfaction. Cornell Hotel and Restaurant Administration Quarterly, 28(4), 44-51. https://doi.org/10.1177/001088048802800415

Cronin Jr, J. J., \& Taylor, S. A. (1992). Measuring service quality: a reexamination and extension. Journal of marketing, 56(3), 55-68. https://doi.org/10.1177/002224299205600304

Cronin Jr, J. J., \& Taylor, S. A. (1994). SERVPERF versus SERVQUAL: reconciling performance-based and perceptions-minus-expectations measurement of service quality. Journal of marketing, 58(1), 125-131. https://doi.org/10.1177/002224299405800110

Chen, C. F., \& Chen, F. S. (2010). Experience quality, perceived value, satisfaction and behavioral intentions for heritage tourists. Tourism management, 31(1), 2935. https://doi.org/10.1016/j.tourman.2009.02.008

Chuang, S. T. (2010). Rural tourism: Perspectives from social exchange theory. Social $\begin{array}{lll}\text { Behavior and Personality, 38(10), } & 1313 .\end{array}$ https://doi.org/10.2224/sbp.2010.38.10.1313

Choi, H., Ann, S., Lee, K. W., \& Park, D. B. (2018). Measuring service quality of rural accommodations. Sustainability, 10(2), 443. https://doi.org/10.3390/su10020443

Demonja, D., \& Ružić, P. (2010). Ruralni turizam u Hrvatskoj: s hrvatskim primjerima dobre prakse i europskim iskustvima. Meridijani.

DeVellis, R. F. (2016). Scale development: Theory and applications (Vol. 26). Sage publications.

Đenadić, M., Muhi, B., \& Jovanović, D. V. (2016). Rural tourism-Serbia's missed chance. Economics of Agriculture, 63(2), 515-529. https://doi.org/10.5937/ekoPolj1602515D 
Đorđević Milošević, S., \& Milovanović, J. (2012). Održivi turizam ufunkciji ruralnog razvoja - Mala poljoprivredna gazdinstva i ruralni turizam uSrbiji. Fakultet za primenjenu ekologiju Futura, Univerzitet Singidunum Beograd. http://dx.doi.org/10.13140/2.1.4392.8326

Frochot, I. (2005). A benefit segmentation of tourists in rural areas: a Scottish perspective. Tourism Management, 26(3), 335-346. https://doi.org/10.1016/j.tourman.2003.11.016

Gašić, M. (2016). Turizam u funkciji razvoja ruralnih područja južne i istočne Srbije. Doktorska disertacija. Ekonomski fakultet Univerziteta u Nišu.

Gašić, M., Perić, G., \& Ivanović, V. (2015). Razvijenost ruralnog turizma u Republici Srbiji. BizInfo (Blace), 6(2), 71-81. https://doi.org/10.5937/BIZINFO1502071G

Grönroos, C. (1984). A Service Quality Model and its Marketing Implications. European Journal of Marketing, 18(4), 36-44. https://doi.org/10.1108/EUM0000000004784

Jurdana, D. S., \& Frleta, D. S. (2012). Tourism development of rural areas-customer perspective. $6^{\text {th }}$ International Conference of the School of Economics and Business „Beyond the Economic Crisis: lessons Learned and Challenges Ahead”, Sarajevo, 191-205.

Kang, G. D. (2006). The hierarchical structure of service quality: integration of technical and functional quality. Managing Service Quality, 16(1), 37-50. https://doi.org/10.1108/09604520610639955

Kljaić Šebrek, J. (2020). Service quality measurement in rural tourism: an application of modified RURALQUAL model. Doctoral dissertation. University of Rijeka, Faculty of Tourism and Hospitality Management in Opatija.

Koster, R. L., \& Lemelin, R. H. (2009). Appreciative inquiry and rural tourism: a case study from Canada. Tourism Geographies, 11(2), 256-269. https://doi.org/10.1080/14616680902827209

Lane, B. (1994). What is rural tourism?. Journal of sustainable tourism, 2(1-2), 7-21. https://doi.org/10.1080/09669589409510680

Lee, B. C., \& Kim, D. K. (2009). Relative importance to tourism decision makers of indicators for sustainable rural tourism development in South Korea: Using AHP approach. Journal of Tourism, 10(2), 21-43.

Loureiro, S. M. C., \& González, F. J. M. (2009). Perceived quality in rural lodgings in Spain and Portugal: the RURALQUAL scale. Portuguese Journal of Management Studies, 14(1), 33-52

Loureiro, S. M. C., \& Kastenholz, E. (2011). Corporate reputation, satisfaction, delight, and loyalty towards rural lodging units in Portugal. International Journal of Hospitality Management, 30(3), 575-583. https://doi.org/10.1016/j.ijhm.2010.10.007

Loureiro, S. M. C. (2012). Tourism in rural areas: foundation, quality and experience. Visions for Global Tourism Industry-Creating and Sustaining Competitive Strategies, S1, InTech, 441-460.

Loureiro, S. M. C., Breazeale, M., \& Radic, A. (2019). Happiness with rural experience: Exploring the role of tourist mindfulness as a moderator. Journal of Vacation Marketing, 25(3), 279-300. https://doi.org/10.1177/1356766719849975

Mandarić, M., Milicević, S., \& Sekulić, D. (2017). Traditional values in the function of promotion of Šumadija and Pomoravlje as rural tourism 
destinations. Economics of Agriculture, 64(2),

787-803. https://doi.org/10.5937/ekoPolj1702787M

Markovic, S., \& Raspor, S. (2010). Measuring Perceived Service Quality Using SERVQUAL: A Case Study of the Croatian Hotel Industry. Management, 5(3), 195-209.

Milićević, S., Podovac, M., \& Čavlin, M. (2015). Resources for development of the Rača Municipality as a rural tourism destination. Economics of Agriculture, 62(3), 751-765. https://doi.org/10.5937/ekoPolj1503751M

Muhi, B. (2010). Ruralni turizam kao faktor revitalizacije sela u Vojvodini-izazovi i pravci razvoja. Ekonomika poljoprivrede, 57(3), 475-485.

Novaković, S., \& Perić, G. (2018). The identification of the main factors of the development of rural tourism on Stara Planina Mountain. $3^{\text {rd }}$ International Thematic Monograph - Thematic Proceedings: Modern Management Tools and Economy of Tourism Sector in Present Era, Belgrade, 775-786. https://doi.org/10.31410/tmt.2018.775

Palmer, A. (2011). Principles of Services Marketing. Mcgraw Hill Higher Education.

Pavlović, N. (2016). Entrepreneurial idea as a chance for rural tourism development. In TISC - Tourism International Scientific Conference Vrnjačka Banja, 552-568.

Parasuraman, A., Zeithaml, V. A., \& Berry, L. L. (1985). A conceptual model of service quality and its implications for future research. Journal of marketing, 49(4), 41-50. https://doi.org/10.1177/002224298504900403

Parasuraman, A., Zeithaml, V. A., \& Berry, L. L. (1988). Servqual: A multiple-item scale for measuring consumer perception of service quality. Journal of retailing, 64(1), 12-40.

Parasuraman, A., Berry, L. L., \& Zeithaml, V. A. (1991). Refinement and reassessment of the SERVQUAL scale. Journal of retailing, 67(4), 420.

Parasuraman, A., Zeithaml, V. A., \& Berry, L. L. (1994). Reassessment of expectations as a comparison standard in measuring service quality: implications for further research. Journal of marketing, 58(1), 111-124. https://doi.org/10.1177/002224299405800109

Pearson, R. H., \& Mundform, D. J. (2010). Recommended sample size for conducting exploratory factor analysis on dichotomous data. Journal of Modern Applied Statistical Methods, 9(2), 359-368. https://doi.org/10.22237/jmasm/1288584240

Podovac, M., Đorđević, N., \& Milićević, S. (2019). Rural tourism in the function of life quality improvement of rural population on Goč mountain. Economics of agriculture, 66(1), 205-220. https://doi.org/10.5937/ekoPolj1901205P

Rabotić, B. (2013). Selektivni oblici turizma. Visoka turistička škola strukovnih studija Beograd.

Radović, G. (2013). Problemi razvoja ruralnog turizma u Republici Srbiji. Agroekonomika, 59-60, 114-123.

Tornjanski, A. (2016). Značaj uslužnog sektora u privredi Srbije. Turističko poslovanje, (18), 81-90. https://doi.org/10.5937/TurPos1618081T

Todorović, M., \& Bjeljac, Ž. (2007). Osnove razvoja ruralnog turizma u Srbiji. Glasnik Srpskog geografskog društva, 87(1), 135-148. https://doi.org/10.2298/GSGD0701135T

UNWTO, Mater plan održivog razvoja ruralnog turizma $u$ Srbiji, https://futurehospitalityleaders.files.wordpress.com/2012/11/master-planodrzivog-razvoja-ruralnog-turizma-u-srbiji.pdf (16 March 2020) 
Veljković, S. (2018). Marketing usluga. Centar za izdavačku delatnost Ekonomskog fakulteta u Beogradu.

Received: 16 June, 2020; Accepted: 29 June, 2020

Rad je primljen: 16.06.2020; Prihvaćen za objavljivanje: 29.06.2020. 
